Cahiers $d u$ MONDE RUSSE

\section{Cahiers du monde russe}

Russie - Empire russe - Union soviétique et États indépendants

45/3-4 | 2004

Varia

Nicolas Werth, préf., « Le pouvoir soviétique et la paysannerie dans les rapports de la police politique (1930-1934)»

\title{
Sarah Davies
}

\section{(2) OpenEdition}

1 Journals

\section{Electronic version}

URL: https://journals.openedition.org/monderusse/4200

DOI: $10.4000 /$ monderusse. 4200

ISSN: $1777-5388$

\section{Publisher}

Éditions de l'EHESS

\section{Printed version}

Date of publication: 1 July 2004

Number of pages: 695-696

ISBN: 2-7132-2009-2

ISSN: $1252-6576$

\section{Electronic reference}

Sarah Davies, "Nicolas Werth, préf., "Le pouvoir soviétique et la paysannerie dans les rapports de la police politique (1930-1934) »", Cahiers du monde russe [Online], 45/3-4 | 2004, Online since 03 June 2009, connection on 03 September 2022. URL: http://journals. openedition.org/monderusse/4200 ; DOI: https://doi.org/10.4000/monderusse.4200

This text was automatically generated on 3 September 2022.

All rights reserved 


\title{
Nicolas Werth, préf., « Le pouvoir soviétique et la paysannerie dans les rapports de la police politique (1930-1934)»
}

\author{
Sarah Davies
}

\section{REFERENCES}

Nicolas WERTH, préf., « Le pouvoir soviétique et la paysannerie dans les rapports de la police politique (1930-1934) ». Bulletin de l'Institut d'Histoire du Temps Présent, 81-82, 2003, $336 \mathrm{p}$.

1 This is an addition to the growing number of collections of documents from the former Soviet archives. It presents to French-speaking readers a selection of documents relating to the period 1930-1934 from the series Sovetskaia derevnia glazami VChK-OGPU-NKVD (Rosspen), and marks a continuation of an earlier Bulletin which covered the period 1918-1929 (Bulletin de l'IHTP, 78 (2001)).

2 The period covered by this volume coincides with the most far-reaching upheaval of the Soviet countryside. It begins with the launch of collectivisation and the policy of "elimination of the kulaks as a class," continues with the famine of 1932-1933, and ends with the "transition year" of 1934. We see these events exclusively through the eyes of the secret police. This differentiates the volume (and the Russian original) from other recent collections, notably Rosspen's series, Tragediia sovetskoi derevni. While the latter includes documents from a range of provenances, the focus of this volume is different: to consider how the secret police interpreted the course of collectivisation and especially the activities of those perceived to be obstructing the process.

3 Secret police surveillance reports, and their limitations, have been the object of numerous studies in recent years, including those of Nicolas Werth himself. Indeed he 
was one of the first to bring these sources to the attention of the public with the Rapports secrets soviétiques (Gallimard, 1994). In his useful introduction to this volume Werth briefly returns to the problems of the sources - the use of formulaic categories and so on, but concludes that they do nevertheless shed some light on the situation in the countryside in the 1930s.

4 As Werth points out, they illuminate in particular the chaotic nature of the assault on the kulaks - the arrests of the wrong people (priests etc.) in some cases, and the problems engendered by the failure to anticipate the consequences of the policy of deportations, such as the high mortality of the spetspereselentsy, and the flight of many of the deportees. They also show how the idea of the enemy changed over the course of 1930-1933, from a quite strictly-defined "class" enemy to a more socially heterogeneous concept. Not surprisingly, given secret police preoccupations, the reports devote much attention to the various forms of "resistance" to collectivisation. Much of this emanated from the peasants themselves, but actions of local officials could be interpreted in this light too (e.g. p. 212-213). The reports also reveal in quite vivid detail how the authorities chose to interpret the famine. Above all, they leave the impression of a regime which was at once terribly powerful and terribly weak.

Given the nature of the sources, this volume does not pretend to offer anything more than a deliberately one-sided perspective on collectivisation and its immediate aftermath. However it succeeds in its stated aim of telling us much about Soviet power, and quite a lot about the peasants too. The problems and potential of these important sources invite further theoretical and comparative analysis, and this volume therefore provides a valuable service in bringing them to a broader audience. 